\title{
Operetta as a Cultural and Historical Symptom: Offenbach through Karl Kraus
}

\author{
Matthieu Guillot \\ Univerza v Strasburgu \\ The University of Strasbourg
}

The Viennese cultural world experienced a strange phenomenon at the beginning of the $2 \mathrm{O}^{\text {th }}$ century, you look at it from a musical or musicological point of view. This was the curious relationship between a famous Austrian writer and polemist, and a popular French operetta composer of the past: Karl Kraus (1874-1936) and Jacques Offenbach (1819-1880). I will try here to examine this original literary phenomenon, which is partly based on Offenbach's operettas. It was previously described by another famous Austrian writer, Elias Canetti (1905-1994), who was an enthusiastic witness of the time in his youth. In his numerous works Canetti often wrote of Karl Kraus, who he called his "master". For him Kraus was the "master of indignation". We shall see later why. Through a transverse axis, I therefore propose to illuminate the real meaning of Offenbach's operetta, beyond its mere musical appearance. Not by the music, known by all, but in its sociological and historical aspects. Such an approach seems possible by analysing Karl Kraus' personal contribution to Offenbach's understanding. Yet his thought is rather complex, sometimes paradoxical and excessive. ${ }^{2}$ But the critical eye of this satirical and polemical writer may allow us to take

1 Elias Canetti, La conscience des mots [The Conscience of Words] (Paris: Albin Michel, 1984), 57. Canetti emphasises with force how Kraus was an absolutely unique speaker (56). See on this subject Matthieu Guillot, "La voie auditive d'Elias Canetti. Un idéal d'entente et d'audience" [Elias Canetti's auditory way. An ideal of understanding and hearing], Conférence, no. 36 (2013).

2 See for instance Edward Timms, "Karl Kraus's Adaptations of Offenbach: The Quest for the Other Sphere," Austrian Studies 13 (2005): 91-108. 
the necessary step back with the operetta, and to understand its meaning differently. Here I will present some essential ideas, will try to show what we can learn from the conjunction of these two poles, and what Kraus' personality and contributions teach us or tell us about the operetta.

\section{A strange encounter?}

At first glance, it seems to be easy to link Karl Kraus to music and musicology: Theodor Adorno, Alban Berg, Arnold Schoenberg and Ernst Krenek are among those who attend his public readings, sometimes even his friends, and are be influenced by him in his language practice, as well as his fascinating use of his voice. ${ }^{3}$ Even Anton Webern refers to him in his writings on new music. ${ }^{4}$ As a famous cultural figure in Vienna, Karl Kraus was in fact part of a current of thought, of a Zeitgeist. It is therefore quite surprising to see his name associated with that of a French operetta composer of the previous century, Jacques Offenbach. How is this possible? Isn't that a contradiction? Would that be the proof of the "miracle of an encounter"? If we look at the portraits of our two protagonists, we can see a strong contrast between the smiling lightness of one (the composer), and the depressing seriousness of the other (the writer). Kraus himself is certainly the opposite of an operetta character: he is rather "the bad conscience of Vienna" (Marcel Ray), "the great inquisitor" (according to the poet Georg Trakl).

Jacques Offenbach, wrote the young Theodor Adorno (in 1932), is "the magician of parody and the parodist of myths." And Kraus himself was

3 See Jacques Bouveresse, "Karl Kraus \& nous. La réalité peut-elle dépasser la satire?", Agone, no. 34 (2005): 208-9. See also the Revue d'Esthétique, no. 9 (1985): Vienne 1880-1938 (Toulouse: Privat, 1985). See among others the articles of Alexander Goehr (about Schönberg and Kraus) and François Decarsin (about Schönberg). Caroline Kohn wrote about Schönberg that "in a letter with a copy of his Treaty of Harmony (Harmonielehre) dedicated to Kraus, he wrote: 'I may have learned more from you than we should for to remain yourself." In Karl Kraus, Le polémiste et l'écrivain, défenseur des droits de l'individu [The Polemicist and the Writer, Defender of the Rights of the Individual] (Paris: Marcel Didier, 1962), 27. See also Susanne Rode, Alban Berg und Karl Kraus. Zur geistigen Biographie der Komponisten der Lulu (Bern: Peter Lang, 1998).

A. Webern, Chemin vers la nouvelle musique [The Path to the New Music] (Paris: J. C. Lattès, 1980), 43-4.

5 See Peter Hawig, 'Die Offenbach-Renaissance findet nicht statt'. Stationen der Autorinszenierung im Spätwerk von Karl Kraus (1926-1936) (Fernwald: Musikverlag Burckhard Muth, 2014), 73-83.

6 Theodor W. Adorno, Moments musicaux [Musical moments] (Genève: Contrechamps, 2003), 35 . 
viewed by Georg Trakl as "the wrathful magician", and we are thus dealing with two kinds of magicians, in a way. But Kraus is not only this magician, as Trakl also wrote in a poem that he is "the supreme judge of intellectual life" and "the high priest of truth". ${ }^{8}$ What truth? This one for instance, when Kraus wrote that the five years of the First World War "are years when operetta figures played the tragedy of humanity" in his book The Last Days of Mankind, published 1922. What does the expression "operetta figures" mean here? But this sentence, which can somehow sum up by itself the dramatic content of the operetta, says even more about, suggesting that behind the operetta characters is played out the entire human tragedy, which is what Offenbach's characters seem to show if we listen to them beyond their appearance. No wonder that Edward Timms, one of the best Kraus biographers, titled his portrait (published 1989) "Apocalyptic Satirist". ${ }^{\text {Io }}$

\section{The intellectual environment}

If the name of Karl Kraus is not related to music itself in cultural history, it is nevertheless attached to Offenbach's operetta, but in a very special way, as we will see. In the 1920 and 30 Kraus made special use of Offenbach's operettas during famous public readings of various texts. This particular use seems to be indicative of several historical symptoms, like the confrontation between France and Austria, but above all the defence of cultural values, and the criticism of political regimes. It is not the musical genre in general that attracts Kraus in such readings, but rather the political and social operetta due to its socio-cultural and sociohistorical content (that will later interest Siegfried $\operatorname{Kracauer}^{\mathrm{II}}$ ). For he sees the society in which he lives (Vienna) as a great operetta which turns into a disaster.

$7 \quad$ Tymothy Youker, Documentary Vanguards in Modern Theatre (New York: Routledge \& Routledge, 2018).

8 Gerald Stieg, "Les guerres de Karl Kraus," Agone, no. 35-6 (2006): 9-10, https://cfedit.flib.fr/agone/libre/ebook_8o4.pdf.

9 Preface of the English translation from Karl Kraus, The last Days of Mankind (New Haven \& London: Yale University Press, 2015).

10 Edward Timms, Karl Kraus - Apocalyptic Satirist: Culture and Catastrophe in Habsburg Vienna (New Haven, London: Yale University Press, 1989).

11 S. Kracauer, Jacques Offenbach ou le secret du Second Empire [Jacques Offenbach and the Paris of His Time] (Paris: Grasset, 1937 [Gallimard, 1994 ( $2^{\text {nd }}$ ed.); Klincksieck, 2018 ( $3^{\text {rd }}$ ed.)]). Later English editions: Siegfied Kracauer, Jacques Offenbach and the Paris of His Time (New York: Alfred A. Knopf, 1938; Zone Books, $2002\left(2^{\text {nd }}\right.$ ed.)).

See later in our last paragraph on this subject. 
A combination of various reasons led Karl Kraus to revive Offenbach's operetta. ${ }^{12}$ In his youth, he liked these works very much, like many others around him, while at the same time being a resolute opponent of the $\mathrm{Vi}$ ennese waltz, being a strong critic of the Austrian culture of his time ${ }^{\mathrm{r} 3}$. $\mathrm{He}$ even considered the French composer to be no less than "the greatest satirical creator of all time and all cultures" ${ }^{\prime 4}$ (1930). Kraus claimed that he was the "re-discoverer" of Offenbach, and from the early days of his newspaper Die Fackel (1899) he devoted several articles to Offenbach and the "Théâtre des Bouffes-Parisiennes". In Austria Kraus launched the Rebirth of Offenbach in an essay of the same title, published in $1927,{ }^{15}$ with a clear critical and polemical intention. He set Offenbach's works against the operettas of F. Lehar and E. Kalman, which he despised. But also against Strauss's Die Fledermaus, a banal imitation in his eyes of the Parisian Life, and despite its musical qualities the source of the cultural disaster he saw at the time. His constant struggle against the "shame of the operetta" was transformed into a struggle against the "desecration" of Offenbach by the Viennese and Berlin theatres. ${ }^{16}$ In his text Grimace about Culture and Stage (Grimassen über Kultur und Bühne), published 1909, Kraus violently criticised Viennese culture, its operettas subjected to fashion and commerce, its mediocrity. For him such works showed decline and decadence. ${ }^{17}$

12 See for instance Anne-Maria Toro Pérez Gruber, Karl Kraus und die Wiener Operette: Die Wiederentdeckung der Operette Jacques Offenbachs im ,Theater der Dichtung' (Saarbrücken: Akademikerverlag, 2012).

13 See Gesa Zur Nieden, “in Paris même malaise’? Karl Kraus’ Paris-Bilder im Zusammenhang mit seiner Offenbach-Renaissance und den 'Offenbach-Schändungen' ab 1927," Etudes Germaniques, no. 283 (2016): 373-92.

14 Die Fackel, no. 827 (1930): 77.

15 Karl Kraus, “'Offenbach-Renaissance', zum Vortag von 'Pariser Leben', Die Fackel, March 1927.

16 See Gerald Stieg, “Offenbach in Wien: Nestroy und Kraus,” in Österreichisch-französische Kulturbeziehungen 1867-1938, eds. Sigurd Paul Scheichl and Karl Zieger (Innsbruck/Valenciennes: Innsbruck University Press/Presses Universitaires de Valenciennes, 2012), 189-201. See also Susanne Rode-Breymann, "'Gegen die Operettenschande der Gegenwart'. Anmerkungen zu den Offenbach-Vorlesungen von Karl Kraus,” in Offenbach und die Schauplätze seines Musiktheaters, ed. Rainer Franke (Laaber: Laaber Verlag, 1999), 855-94.

17 Karl Kraus, "Grimassen über Kultur und Bühne” [Grimace about Culture and Stage] (Januar 1909), textlog.de, https://www.textlog.de/39188.html. 


\section{The artistic context}

It is well known that Karl Kraus, among his numerous activities in this period (1900-1935), read in public (and also sang, even if he wasn't himself a musician ${ }^{18}$ some libretti from Offenbach's operettas - sometimes accompanied by a hidden piano being played behind a curtain. ${ }^{19}$ However, one fact here may seem quite surprising - at least as far as I am concerned. The polemist (this "polemical genius" wrote Adorno ${ }^{2 \circ}$ ) made many adaptations of Offenbach operettas by translating the libretti himself (that were then published in 1927, 1931 and 1932). ${ }^{21}$ Like an actor with different voices (called "acoustic masks" by Canetti, who admired Kraus' "maestria of the acoustic quote"), ${ }^{22}$ he read the texts in the form of speeches sung in a particularly flexible and modulated voice (it was not a Sprechgesang, but rather a Satzmelodie, as witnesses noted). The German philosopher Walter Benjamin, who heard and saw Kraus in Berlin, meticulously analysed such a way of articulating the text. ${ }^{23}$ From 1926 to 1935 , Kraus read Offenbach around 120 times in his public lectures (along with 12 that were broadcast on the radio). He read from 14 Offenbach operettas, such as Parisian Life, his favourite. In fact, Kraus used the non-musical content of the works in these readings, deliberately amplifying certain features through his critical filter. And this is where "the true mask of satirical" appears, according to Benjamin. ${ }^{24}$ As Harry Zohn pointed out,

18 Kraus said himself: "I don't understand anything in music" ("Von Musik verstehe ich nichts; von Literatur einiges, vom akademischen Verband für Literatur und Musik alles"). Quoted by Burkhard Müller, Karl Kraus: Mimesis und Kritik des Mediums (Stuttgart: J. B. Metzler, 1995), 325. This is what Walter Benjamin called about Kraus a "subversive dilettantism" (ibid., 324).

19 See Georg Knepler, Karl Kraus liest Offenbach. Erinnerungen, Kommentare, Dokumentationen (Vienna: Löcker, 1984). For four years (1928-31), G. Knepler provided the piano accompaniment, from behind a curtain, for K. Kraus's Offenbach recitations.

20 Theodor W. Adorno, Théorie esthétique [Aesthetic Theory] (Paris: Klincksieck, 1989), 99. (It can be assumed that the young Adorno here is influenced by the public readings of Kraus).

21 Madame l'Archiduc, Perichole and VertVert. For the modern edition see K. Kraus, Theater der Dichtung. Jacques Offenbach, ed. Christian Wagenknecht (Frankfurt: Suhrkamp, 1994).

22 Canetti, La conscience des mots, 55.

23 Walter Benjamin, “Karl Kraus (1931)," in: Karl Kraus, Cette grande époque [In These Great Times] (Paris: Payot \& Rivages, 200o), 13-84. See on this subject Matthias Nöther, "Operette als Vorhang. Benjamin beobachtet Karl Kraus' Offenbach-Vorlesungen," in Klang und Musik bei Walter Benjamin, eds. T.R. Klein and A. Trautsch (München: Wilhelm Fink Verlag, 2013), 95-103.

Ibid., 63. 
the socially critical [...] of the French composer provided an important counterpoise to the satirist's surroundings, and it is significant that Kraus [...] who used [Offenbach] for his depiction of an antibourgeois world, created almost 350 Zeitstrophen (topical stanzas inspired by his various campaigns and polemics) for those operettas. ${ }^{25}$

\section{A "theatre of poetry"}

Kraus performed extracts from operettas in his famous one-man performances: he was alone on the stage, where all decor is absent and he was the only "actor" at the service of the sacralised words of his favourite authors, such as Offenbach. Thus, Kraus created what he called a "theatre of poetry" (Theaterdichtung). The appeal of this to Kraus lay in part in Offenbach's use of satire and parody as a means of unmasking the hypocrisy underlying the surface appearance of the social and political life of his times. Indeed, following Kraus' state of mind as well as his critical thought, his use of operetta reveals its potential to hide and disguise reality - reveals the "untruth" in the sense of Adorno. For Kraus, who rediscovered Offenbach through the prism of his time, "the laws of chaos are the true foundation of the operetta": they combine the soothing effect of music with an innocent gaiety that suggests, in confusion, the true absurdity of the world. ${ }^{26}$

Kraus crosses the surface of things to penetrate the murky thickness of reality and its truth: is an operetta only what it offers on the surface through its music and its spectacle? Or does it hide another dimension, does it designate another absent aspect? In other words, what is the operetta genre a symptom of? If we decide to listen and to look at Offenbach's works throughout a critical filter, one can understand that they are maybe more a striking symptom than a simple musical genre. They oscillate between frivolous and serious music, between entertainment and the true reflection of the spirit of their time. This is why the real content can be analysed based on the writings of Karl Kraus. What is also in question through the adaptation of Offenbach by Kraus, is this mixture of banal frivolity (deceptive appearance) and extreme gravity (concealed content). 


\section{A nonsense music?}

Writing of Offenbach, Adorno perceived in the music "the thin veil that isolates from the world threatening from the depths that of light." For "the two spheres mingle in the intoxication of the parody." In Offenbach, he wrote, "idyll [...] discovers that bourgeois freedom is an illusion, and its joy turns into an infernal laugh, as in a game of distorted mirrors. ${ }^{327}$ What the musical content of an operetta reveals to us is also what Walter Benjamin observes. Let us note to Benjamin's comment, here, since he was himself in the audience for Kraus' public lectures in Berlin:

The operetta seals the transfiguration of stupidity through music [...] the bourgeois trinity of truth, beauty and good is brought together in a new staging with musical accompaniment, to give its number on the trapeze of idiocy. The absurd is true, beautiful stupidity, good weakness. This is the secret of Offenbach: in the absurd good manners displayed in public [...] we see the deep sense of private indecency appear.

Benjamin wonders if "music would not take the place of moral order,"28 although as a writer and philosopher he is of course an observer outside of music. It is true that the music composed by Offenbach divides opinions (the composer called himself "the mutual insurer against public boredom"). Adorno explains it in these terms: "According to Willy Haas' pretty formula, there is 'good literature' of poor quality and 'bad literature' of good quality. The same is true of music." ${ }^{\text {"29 }}$ Offenbach must nevertheless be recognised for his real invention: satirical, political operas, where music disguises and mocks, where the text skips into bursts of laughter. In a letter to his friend Peter Gast (1888), Nietzsche wrote that he found in Offenbach a "state of exuberant buffoonery but in a classic taste, of an absolute logic." ${ }^{\text {"3o }}$ Debussy recognised his "transcendental irony", and the operetta composer Claude Terrasse (1867-1923) defended his musical value, writing that Offenbach was a "humourist musician" and "an ironist who is never low or flat."

27 Th. W. Adorno, Quasi una fantasia (Paris: Gallimard, 1982), 28, 31.

28 Benjamin, "Karl Kraus," 60-1.

29 Adorno, Théorie esthétique, 396. Willy Haas (1891-1973) was a German film critic and screenwriter.

30 Friedrich Nietzsche, Lettres à Peter Gast, II (Monaco: Editions du Rocher, 1957), 301.

31 Claude Terrasse, Euvres complètes. Ecrits non musicaux (Paris: Ed. du Fourneau, 1997), 14, 20. 
For Kraus the conception of music reflects a very personal vision: in his essay Grimace about Culture and Stage, he wrote, in a passage that can summarise his theory of operetta:

The function of music: to loosen the cramp of life, to give the mind rest and to relaunch the activity of the mind - this function, fused with the effect of the stage, makes the operetta, and she has reconciled herself with the theatrics exclusively in this art form. For the operetta presupposes a world in which the causality is lifted, according to the laws of chaos from which the other world was created, the song is happily continued and certified as a means of communication. If the dissolving effect of music is combined with irresponsible cheerfulness, which in this confusion gives us an idea of our real trade tendencies, then the operetta proves to be the only dramatic form perfectly suited to the theatrical possibilities. The spectacle can only prevail in spite of or contrary to the idea, and the opera, through the incongruity of a possible seriousness with the wondrous habit of singing itself, is ad absurdum. In the operetta, the absurdity is preordained. ${ }^{32}$

\section{Operetta as a cultural tool}

Some twenty years ago, the French sociologist Pierre Bourdieu rightly said about Kraus that

he is a 'sociological artist', in the sense that his actions are sociological interventions, that is to say, 'experimental actions' aimed at bringing hidden properties or tendencies of the intellectual field to reveal themselves, to unmask themselves. ${ }^{33}$

Indeed, Kraus used the operetta as a pretext for his own social and political criticism: in his hands, through his voice and texts, it serves him as a tool to get his message across. For he found in this genre - in the stories, libretti, and characters - material that was conducive to criticism. It is therefore as a critical object that Kraus uses the operetta, with the firm intention of unmasking the unworthy Viennese culture, as well as the human behav-

32 Kraus, "Grimassen über Kultur und Bühne".

33 Text written in 1999 (Pierre Bourdieu, "Un manuel de combattant contre la domination symbolique," in: Pierre Bourdieu, Interventions 1961-2001. Science sociale et action politique (Marseille: Agone, 2002)), quoted in Agone, no. 35-6 (2006): 105, https://cfedit.flib.fr/agone/libre/ebook_804.pdf. 
iours that revolt him. Thus we can see the singular use that Kraus made of Offenbach's texts (through translations and personal additions) - these "nonsense texts full of meaning for which Karl Kraus could be ignited"34 - to place them in a contemporary context, and thus the relationship he established between a literary and musical form from the Parisian past, and a form of social criticism in the Austrian present.

\section{A "second sociology" of Operetta: S. Kracauer}

Finally, to supplement the above remarks, let us very briefly point out that the position held by Kraus vis-à-vis Offenbach's operettas, may also be clarified a posteriori by the analysis of the German sociologist Siegfried Kracauer (1889-1966) on Offenbach and his time, in his famous book written between 1934 and 1936 when he lived in France. ${ }^{35}$ According to Kracauer, the composer "unmasked the powerful of the earth and the great opera." But mostly he warns the reader in the first few pages that

contrary to what foolishness likes to say, his mocking voice never defiles sacrosanct institutions, and he entertains himself at their expense only when they pretend to be sacrosanct. [...] It is by laughing that he [Offenbach] brings down the mask of lying dignity, illusory authority, usurped power. Is it for the sole pleasure of thwarting them? No, he seems to obey an imperious impulse of all his being haunted by the vision of a clear humanity, free and delivered from all nightmares. ${ }^{36}$

This perspective that brings the two authors together is still valued today, as evidenced by a recent German radio broadcast (SWR2). ${ }^{37}$

34 Th. W. Adorno, Introduction à la sociologie de la musique [Introduction to the Sociology of Music] (Genève: Contrechamps, 1994), 28.

35 Kracauer, Jacques Offenbach ou le secret du Second Empire. About the circumstances of this book, see Michel Espagne, "Siegfried Kracauer et Paris", Pardès, no. 14 (1991): 146-71; and Olivier Agard, "L'exil parisien de Siegfried Kracauer," Atala, no. 9 (Rennes: s. n., 2006), 59-71. See also Esther Marian, “Das Pfeifen im Walde. Über Kitsch, Utopie und Grauen,” Sans phrase: Zeitschrift für Ideologiekritik, Heft 1, eds. Manfred Dahlmann and Gerhard Scheit (Wien: ça ira-Verlag, 2012), 3-15.

36 Kracauer, Jacques Offenbach ou le secret du Second Empire, 15-9.

37 Werner Klüppelholz, "Jacques Offenbach bei Karl Kraus und Siegfried Kracauer," produced by SWR2, broadcast program, June 2019. 


\section{Conclusion}

In this paper I have tried to emphasise the strange and unexpected duo formed by an Austrian writer interested in operetta, and a popular French composer of the $19^{\text {th }}$ century. As a cultural phenomenon in itself, the writings as well as the public lectures of Karl Kraus formed an original, almost unique approach to operetta, building an original form by extension of Offenbach's works. The "meeting" between Kraus and Offenbach (i.e. the use of operetta by Kraus), the mutual illumination of the analyses of Kraus and Kracauer on the operetta of Offenbach, constitute an interpretive axis that differs from and complements traditional musicological analysis.

Through his personal vision and reconstruction, these operettas are interpreted by the Austrian writer as a particularly striking historical and cultural symptom. Through his deconstruction, Kraus brings them back to life with the assumed objective of exposing and intensifying his critical verbal content, stripped of its musical pomp and appeal. By stripping its real content, he thus shows his readers and listeners that under the most superficial appearance of the operetta (that of entertainment, a show or even circus, as seen, and heard, by the many blows of cymbals on the percussion stands), a much less happy, more tragic truth manifests itself. Finally, for an uninitiated operetta listener (which I am, personally), Kraus offers an original path towards in-depth knowledge of the content of Offenbach's works, as the Austrian writer undoubtedly makes it possible to understand it more profoundly.

I sincerely thank Professor Gerald Stieg and Professor Marc Lacheny for their valuable and dedicated help with this work.

\section{Bibliography}

Adorno, Theodor W. Quasi una fantasia. Paris: Gallimard, 1982.

Adorno, Th. W. Théorie esthétique [Aesthetic Theory]. Paris: Klincksieck, 1989.

Adorno, Th. W. Introduction à la sociologie de la musique [Introduction to the Sociology of Music]. Genève: Contrechamps, 1994.

Adorno, Th. W. Moments musicaux [Musical moments]. Genève: Contrechamps, 2003.

Agard, Olivier. "L'exil parisien de Siegfried Kracauer." Atala, no. 9, 59-71. Rennes: s. n., 2006. 
Benjamin, Walter. “Karl Kraus (1931).” In: Karl Kraus, Cette grande époque [In These Great Times], 13-84. Paris: Payot \& Rivages, 2000.

Bourdieu, Pierre. "Un manuel de combattant contre la domination symbolique.” In: Pierre Bourdieu, Interventions 1961-20o1. Science sociale et action politique. Marseille: Agone, 2002. Quoted in Agone, no. 35-6 (2006): 105. https://cfedit.flib.fr/agone/libre/ebook_804.pdf.

Bouveresse, Jacques. "Karl Kraus \& nous. La réalité peut-elle dépasser la satire?” Agone, no. 34 (2005): 179-219.

Canetti, Elias. La conscience des mots [The Conscience of Words]. Paris: Albin Michel, 1984.

Die Fackel, no. 827 (1930): 77.

Espagne, Michel. “Siegfried Kracauer et Paris.” Pardès, no. 14 (1991): 146-71.

Guillot, Matthieu. “La voie auditive d'Elias Canetti. Un idéal d'entente et d'audience" [Elias Canetti's auditory way. An ideal of understanding and hearing]. Conférence, no. 36 (2013): 359-8o.

Hawig, Peter. 'Die Offenbach-Renaissance findet nicht statt'. Stationen der Autorinszenierung im Spätwerk von Karl Kraus (1926-1936). Fernwald: Musikverlag Burckhard Muth, 2014.

Klüppelholz, Werner. "Jacques Offenbach bei Karl Kraus und Siegfried Kracauer," produced by SWR2, broadcast program, June 2019.

Knepler, Georg. Karl Kraus liest Offenbach. Erinnerungen, Kommentare, Dokumentationen. Vienna: Löcker, 1984.

Kohn, Caroline. Karl Kraus: Le polémiste et l'écrivain, défenseur des droits de l'individu [The Polemicist and the Writer, Defender of the Rights of the Individual]. Paris: Marcel Didier, 1962.

Kracauer, Siegfried. Jacques Offenbach ou le secret du Second Empire [Jacques Offenbach and the Paris of His Time]. Paris: Grasset, 1937 [Gallimard, 1994 ( $2^{\text {nd }}$ ed.); Klincksieck, 2018 ( $3^{\text {rd }}$ ed.)].

Kraus, Karl. "Grimassen über Kultur und Bühne” [Grimace about Culture and Stage] (Januar 1909). textlog.de, https://www.textlog.de/39188.html.

Kraus, Karl. “'Offenbach-Renaissance', zum Vortag von 'Pariser Leben'.” Die Fackel, March 1927.

Kraus, Karl. Theater der Dichtung. Jacques Offenbach. Edited by Christian Wagenknecht. Frankfurt: Suhrkamp, 1994.

Kraus, Karl. The last Days of Mankind, Preface. New Haven \& London: Yale University Press, 2015. 
Marian, Esther. "Das Pfeifen im Walde. Über Kitsch, Utopie und Grauen." Sans phrase: Zeitschrift für Ideologiekritik, Heft 1, edited by Manfred Dahlmann and Gerhard Scheit, 3-15. Wien: ça ira-Verlag, 2012.

Müller, Burkhard. Karl Kraus: Mimesis und Kritik des Mediums. Stuttgart: J. B. Metzler, 1995.

Nietzsche, Friedrich. Lettres à Peter Gast, II. Monaco: Editions du Rocher, 1957.

Nöther, Matthias. “Operette als Vorhang. Benjamin beobachtet Karl Kraus' Offenbach-Vorlesungen.” In Klang und Musik bei Walter Benjamin, edited by T. R. Klein and A.Trautsch, 95-103. München: Wilhelm Fink Verlag, 2013.

Revue d'Esthétique, no. 9 (1985): Vienne 1880-1938. Toulouse: Privat, 1985.

Rode, Susanne. Alban Berg und Karl Kraus. Zur geistigen Biographie der Komponisten der Lulu. Bern: Peter Lang, 1998.

Rode-Breymann, Susanne. “'Gegen die Operettenschande der Gegenwart'. Anmerkungen zu den Offenbach-Vorlesungen von Karl Kraus.” In Offenbach und die Schauplätze seines Musiktheaters, edited by Rainer Franke, 855-94. Laaber: Laaber Verlag, 1999.

Stieg, Gerald. “Les guerres de Karl Kraus.” Agone, no. 35-6 (2006): 9-10. https:// cfedit.flib.fr/agone/libre/ebook_804.pdf.

Stieg, Gerald. “Offenbach in Wien: Nestroy und Kraus.” In Österreichisch-französische Kulturbeziehungen 1867-1938/France-Autriche: leurs relations culturelles de 1867 à 1938, edited by Sigurd Paul Scheichl and Karl Zieger, 189-201. Innsbruck/Valenciennes: Innsbruck University Press/Presses Universitaires de Valenciennes, 2012.

Terrasse, Claude. Euvres complètes. Ecrits non musicaux [Non-musical Writings]. Paris: Ed. du Fourneau, 1997.

Timms, Edward. Karl Kraus - Apocalyptic Satirist: Culture and Catastrophe in Habsburg Vienna. New Haven, London: Yale University Press, 1989.

Timms, Edward. "Karl Kraus's Adaptations of Offenbach: The Quest for the Other Sphere." Austrian Studies 13 (2005): 91-108.

Toro Pérez Gruber, Anne-Maria. Karl Kraus und die Wiener Operette: Die Wiederentdeckung der Operette Jacques Offenbachs im 'Theater der Dichtung'. Saarbrücken: Akademikerverlag, 2012.

Webern, A. Chemin vers la nouvelle musique [The Path to the New Music]. Paris: J.C. Lattès, 1980.

Youker, Tymothy. Documentary Vanguards in Modern Theatre. New York: Routledge \& Routledge, 2018. 
Zohn, Harry. Karl Kraus and the Critics. Columbia: Camden House, 1997.

Zur Nieden, Gesa. “'in Paris même malaise'? Karl Kraus' Paris-Bilder im Zusammenhang mit seiner Offenbach-Renaissance und den 'Offenbach-Schändungen' ab 1927," Études Germaniques, no. 283 (2016): 373-92. 